\title{
Analisis Aktor dalam Perumusan Model Kelembagaan Pengembangan Hutan Rakyat di Kabupaten Bogor
}

\author{
Actor Analysis in Formulating Institutional Models \\ for Community-Forest Development in Bogor Regency
}

\begin{abstract}
Tatan Sukwika ${ }^{*}$
${ }^{1}$ Program Studi Teknik Lingkungan, Fakultas Teknik, Universitas Sahid, Jalan Prof. Dr. Soepomo Nomor 84, Jakarta 12870, Indonesia; *Penulis korespondensi.e-mail: tatan.swk@gmail.com
\end{abstract}

(Diterima: 20 Februari 2018; Disetujui: 27 Juni 2018)

\begin{abstract}
Bogor regency has an area of 16,945 hectares' community-forests or 22\% of the forest area in the regency. Institutional problems of community-forest management include weak interaction of actors within the organization. Since the organization is part of the institution, its existence becomes an important technical part in securing the operation of the institution. Objectives of this research on analyzing actors and the institution in the community-forest area are: (1) to determine the dominant key actors in community-forests action arena; and (2) to formulate community-forests development institutional models. Qualitative descriptive analysis of actors and institutions employs content analysis. Key actors analysis utilized ISM (Interpretive Structural Modeling) analysis methods. Results of the analysis identified seven key actors in community forest management, namely UPTD BP3K, landowners who lives outside the village, farmer landowners, land tenants, farm labors, lumbermens, and middlemen. Of the seven key actors, four key actors are the most dominant in the community-forest action arena, which are farmer landowners, farm labors, lumbermens and middlemen. There are three models of community-forest management institutions for capacity development actors, namely the institutional model related to venture capital, handling waste of resources, and coordination. This study recommends the necessity to strengthen dominant actors at site level according to the criteria of efficiency, equity, and sustainability. The policy makers need to optimize the capacity and coordination function of government agencies through the institutional coordination model.
\end{abstract}

Keywords: actor, community-forest, content analysis, institutional, Interpretive Structural Modeling

\begin{abstract}
ABSTRAK
Kabupaten Bogor memiliki hutan rakyat seluas 16,945 hektar atau 22 persen dari luas hutan yang ada di Kabupaten Bogor. Persoalan kelembagaan pengelolaan hutan rakyat yang ditemukan di Kabupaten Bogor diantaranya mengenai interaksi aktor yang lemah dalam organisasi. Organisasi merupakan bagian dari kelembagaan, sehingga keberadaan organisasi menjadi bagian teknis yang penting yang dapat menjamin beroperasinya kelembagaan. Tujuan penelitian analisis aktor dan kelembagaan di kawasan hutan rakyat adalah: (1) menentukan aktor kunci yang dominan dalam ruang arena aksi hutan rakyat; dan (2) merumuskan model-model kelembagaan pengembangan hutan rakyat. Analisis deskriptif kualitatif aktor dan institusi menggunakan analisis isi. Analisis aktor kunci menggunakan metode analisis Interpretive Structural Modeling (ISM). Hasil analsis menemukan tujuh aktor kunci dalam pengelolaan hutan rakyat, yaitu UPTD BP3K, pemilik lahan yang tinggal
\end{abstract}


dari luar desa, petani pemilik, penggarap, buruh tani, penebang, dan pedagang perantara (tengkulak). Dari tujuh aktor kunci, terdapat empat aktor kunci yang paling dominan di dalam ruang arena aksi hutan rakyat adalah petani pemilik, penggarap, penebang pohon, dan tengkulak. Terdapat tiga model kelembagaan pengelolaan hutan rakyat untuk pengembangan kapasitas aktor yaitu model kelembagaan modal usaha, model kelembagaan penanganan pemborosan sumberdaya, dan model kelembagaan koordinasi. Penelitian ini merekomendasikan perlu penguatan aktor dominan di tingkat tapak sesuai kriteria efisiensi, keadilan, dan keberlanjutan. Para pelaku kebijakan perlu mengoptimalkan fungsi kapasitas dan koordinasi instansi pemerintah melalui model kelembagaan koordinasi.

Kata Kunci: aktor, analisis isi, kelembagaan, Interpretive Structural Modeling, hutan rakyat

\section{PENDAHULUAN}

Kabupaten Bogor memiliki hutan rakyat seluas 16,945 hektar atau 22 persen dari luas hutan yang ada di Kabupaten Bogor. Hutan rakyat merupakan salah satu sumber daya yang memberikan manfaat besar bagi kesejahteraan manusia, baik manfaat yang dirasakan secara langsung, maupun yang dirasakan secara tidak langsung. Manfaat langsung seperti penyediaan kayu, penunjang ketersediaan bahan makanan dan minuman, bahan obat-obatan, dan satwa. Manfaat tidak langsung hutan rakyat seperti manfaat perlindungan dan pengaturan tata air, sarana untuk penanggulangan lahan kritis, konservasi lahan, perlindungan hutan, serta pencegahan erosi. Manfaat tersebut dapat optimal apabila aspek kelembagaan pengelolaan hutan rakyat memiliki kesesuaian dengan nilai dan norma yang terdapat di masyarakat. Kajian terkait peran kelembagaan di hutan rakyat terdapat dalam penelitian Coleman (2009); Caballero (2014); Osei-Tutu et al. (2015); Sukwika (2016); Sukwika et al. (2016).

Tidak ada masyarakat atau organisasi yang bisa eksis tanpa interaksi dengan masyarakat atau organisasi lain yang saling mengikat. Organisasi sendiri merupakan bagian dari kelembagaan, sehingga keberadaan organisasi menjadi bagian teknis yang penting yang menjamin beroperasinya kelembagaan. Kelembagaan bisa berkembang baik jika ada infrastruktur kelembagaan (institutional infrastructure), ada penataan kelembagaan (institutional arrangements), dan mekanisme kelembagaan (institutional mechanism).
Perpaduan antara berbagai pendekatan ini bisa menghasilkan analisis kelembagaan (institutional analysis) yang memadai. Logika analisis kelembagaan bisa dipakai untuk menjelaskan kegagalan pengambil kebijakan terhadap model pembangunan. Penataan institusi (institutional arrangements) dapat ditentukan oleh dua unsur, yaitu (1) aturan operasional untuk pengaturan pemanfaatan sumber daya; (2) aturan kolektif untuk menentukan atau menegakan aturan organisasi, mengubah aturan operasional dan mengatur hubungan kewenangan organisasi (Kyfyak, 2012; Tiwari et al., 2013; Hinings et al., 2017; Mokhele, 2018).

Kelembagaan (institutional) merupakan sebutan yang lebih tinggi, mencakup perilaku dan struktur yang sejajar kedudukannya dengan sebutan organisasi. Sedangkan perilaku dibentuk dari norma, nilai, dan lain-lain. Sementara strukur berperan sebagai aspek statis yang menjamin berlangsungnya suatu kelembagaan. Kelembagaan bisa diartikan sebagai perangkat lunak, aturan main, keteladanan, rasa percaya, serta konsistensi kebijakan yang diterapkan di dalamnya. Kelembagaan tidak hanya sebatas hubungan kerja di dalam dan antar lembaga. Kartodihardjo (2006) menekankan bahwa kelembagaan juga dapat menyangkut hubungan sosial kemasyarakatan, rasa percaya, tindakan bersama, serta pengaruh hak-hak terhadap kearifan dalam pengelolaannya.

Institusi atau lembaga berkenaan dengan konsep-konsep tentang koordinasi, integrasi usaha, kontrak, struktur, biaya dari suatu 
perubahan, serta aturan main baik tertulis maupun tidak. Institusi dapat mempengaruhi keputusan-keputusan yang diambil oleh individu maupun kelompok yang sedang menjalankan upaya pengelolaan hutan rakyat. Institusi hutan rakyat dipengaruhi oleh faktor eksogen berupa kondisi biofisik wilayah, atribut masyarakat dan aturan yang digunakan dalam aktivitas pengelolaan hutan rakyat. Interaksi antar aktor menentukan situasi yang berlangsung di dalam hutan rakyat. Aktor dalam suatu situasi bisa dianggap sebagai individu tunggal atau sebagai kelompok yang berfungsi sebagai aktor korporat (Ostrom, 2011). Masing-masing aktor di dalam masyarakat memiliki kepentingan dan sumber daya yang berbeda sehingga dalam interaksinya ditentukan oleh besarnya kekuatan yang dimiliki dan jaringan yang dibangun di dalam masyarakat. Jaringan aktor memperjuangkan tujuannya melalui aksi bersama sesuai dengan permasalahan yang dihadapi bersama (Rout, 2011; Canadas et al., 2016).

Persoalan umum kelembagaan yang sering ditemukan di kawasan hutan rakyat yaitu antara lain, berupa permasalahan pada kelembagaan unit usaha masyarakat, di mana, pada kondisi ini organisasi petani lemah, komitmen terhadap aturan rendah, kebutuhan aspek pembiayaan tinggi, pemanfaatan sumber daya tidak sebanding dengan produktivitas yang dihasilkan, koordinasi aktor dalam kelembagaan hutan rakyat pasif. Hasil kajian Setiawan et al. (2014) menemukan indikasi pola pengembangan dan kelembagaan kelompok tani hutan rakyat belum terkoordinasi secara baik.

Berdasarkan indikasi-indikasi tersebut di atas, maka penelitian ini mencoba menganalisis aktor-aktor yang terlibat dan menemukenali interaksi peran-peran yang dilakukan selama ini di dalam sebuah ruang arena aksi hutan rakyat di Kabupaten Bogor.

Efektivitas kinerja kelembagaan dalam pengelolaan keberlanjutan hutan rakyat dapat dianalisis berdasarkan: (1) aktivitas pengelolaan lahan dalam kelompok hutan rakyat, upaya kolektif terhadap kendala dalam pengelolaan hutan rakyat; (2) tenaga penyuluh dan pendampingan; (3) ketersediaan nilai-nilai, norma dan aturan main di masyarakat dalam pengelolaan hutan rakyat; dan (4) interaksi dalam kelompok atau lembaga yang berperan serta aktif dalam pengelolaan hutan rakyat. Tujuan penelitian dilakukannya analisis aktor dan kelembagaan di kawasan hutan rakyat adalah: (1) mengidentifikasi aktor kunci yang dominan dalam ruang arena aksi hutan rakyat; dan (2) merumuskan model-model kelembagaan pengembangan hutan rakyat.

\section{METODE PENELITIAN}

Analisis aktor yang berperan sebagai aktor kunci dalam pengelolaan hutan rakyat digunakan metode analisis interpretive structural modeling (ISM). ISM merupakan salah satu alat strukturisasi dalam teknik permodelan deskriptif. Model-model struktural dihasilkan guna memotret perihal yang kompleks dari suatu sistem melalui pola yang dirancang dengan menggunakan grafis dan kalimat (Eriyatno, 2003). Teknik ISM merupakan sebagai basis pengetahuan yang bermanfaat untuk menyusun perencanaan strategi pengembangan pengelolaan hutan rakyat yang terpadu baik secara lintas-pelaku dan lintas-sektor melalui kelembagaan. ISM adalah suatu teknik yang digunakan dalam permodelan yang mampu mensinkronisasi pendapat para ahli dalam memberikan gambaran yang konkrit tentang struktur hierarki subelemen dari setiap elemen sistem, dan dalam menemukan sub-elemen kunci serta karakter setiap sub-elemen (Saxena et al., 2006; Sushil, 2013). Langkah-langkah penerapan ISM (Saxena et al., 1992): (a) identifikasi elemen dan sub-elemen melalui brainstorming; (b) perumusan hubungan kontekstual; (c) perumusan matrik interaksi tunggal terstruktur (structural self interaction matrix/SSIM) melalui survei pakar; (d) mengubah matrik SSIM menjadi reachability matrix (RM) dan kemudian menjadi matriks biner; (e) klasifikasi elemen dalam level yang berjenjang; (f) matrik canonical yaitu pengelompokkan elemenelemen dalam level yang sama; (g) menyusun matrik digraph (directional graph) yaitu sebuah grafik dari elemen-elemen yang saling berhubungan secara langsung pada suatu level hierarki; dan (h) ISM dibangkitkan dengan memindahkan seluruh jumlah elemen dengan deskripsi elemen aktual. 
Penilaian hubungan kontekstual pada matriks perbandingan berpasangan menggunakan simbol (Saxena et al., 1992):

$$
\begin{aligned}
\mathrm{V}_{\mathrm{jika}} \mathrm{e}_{\mathrm{ij}} & =1 \text { dan } \mathrm{e}_{\mathrm{ji}}=0 \\
\mathrm{~A} \mathrm{jika} \mathrm{e}_{\mathrm{ij}} & =0 \text { dan } \mathrm{e}_{\mathrm{ji}}=1 \\
\mathrm{X} \mathrm{jika} \mathrm{e}_{\mathrm{ij}} & =1 \text { dan } \mathrm{e}_{\mathrm{ji}}=1 \\
\mathrm{O} \mathrm{jika} \mathrm{e}_{\mathrm{ij}} & =0 \text { dan } \mathrm{e}_{\mathrm{ji}}=0
\end{aligned}
$$

Keterangan:

nilai $\mathrm{e}_{\mathrm{ij}} \quad=1$ adalah ada hubungan kontekstual antara sub elemen ke-i dan ke-j.

nilai $\mathrm{e}_{\mathrm{ij}}=0$ adalah tidak ada hubungan kontekstual antara sub elemen ke-i dan ke-j.

Hasil penilaian tersusun dalam structural self interaction matrix (SSIM). SSIM dibuat dalam bentuk tabel reachability matrix (RM) dengan mengganti $\mathrm{V}, \mathrm{A}, \mathrm{X}$, dan $\mathrm{O}$ menjadi bilangan 1 dan $0 . \mathrm{V}(1,0), \mathrm{A}(0,1), \mathrm{X}(1,1)$, dan $\mathrm{O}$ $(0,0)$. Matriks tersebut dikoreksi lebih lanjut sampai menjadi matriks tertutup yang memenuhi aturan transitivity (Saxena et al., 1992).

Berdasarkan hasil analisis ISM, selanjutnya, aktivitas aktor dan kelembagaan dideskripsikan secara kualitatif menggunakan analisis isi (content analysis). Analisis tersebut dilakukan terhadap interaksi aktor-aktor yang berpengaruh dalam sub-elemen kelembagaan pengelolaan hutan rakyat baik yang bersifat vertikal maupun horisontal. Di mana penekanannya terkait dengan isi teks aturan di dalam ruang arena aksi hutan rakyat, koordinasi antar pelaku, dan keterkaitan antar isi aturan dan kebijakan, seperti norma (aturan lokal) dalam kelompok tani hutan rakyat, aturan pemerintah terkait penyuluhan, konservasi, dan kehutanan rakyat. Teknik ini merupakan strategi verifikasi kualitatif yang abstrak untuk analisis data-data kualitatif (Hashemnezhad, 2015).

Dalam penelitian ini, terdapat dua sampling, yaitu (1) sampling pakar diambil dari stakeholder sebagai key informan untuk memperoleh informasi terkait keberadaan aktor utama dan aktor sekunder; dan (2) sampling petani diambil dari kelompok tani hutan rakyat untuk memperoleh informasi persepsi kondisi sosial, ekonomi dan lainnya. Sampel pakar sebagai key informan sebanyak enam orang yang diambil dari unsur pemerintah, masyarakat, dan pemerhati kehuhatan rakyat di Kabupaten Bogor. Informan dalam penelitian ini mereka yang mengetahui dan memiliki berbagai informasi pokok secara mendalam terhadap peran aktor baik langsung maupun tidak langsung terlibat dalam interaksi sosial di dalam ruang hutan rakyat (Suyanto, 2005). Penentuan sampel responden dari key informan tersebut dilakukan secara purposive sampling dan dengan teknik snowball sampling. Sedangkan metode penentuan sampel petani dilakukan secara purposive. Sampel diambil secara multistage random sampling berdasarkan populasi petani hutan rakyat yang tergabung dalam kelompok tani hutan rakyat. Petani yang tergabung dalam KTH (kelompok tani hutan) Kabupaten Bogor sebanyak 8,981 orang yang berasal dari 312 tingkat kemampuan kelompok (Distanhut, 2014). Jumlah responden ditentukan dengan menggunakan pendekatan Taro Yamane (1967) yang dikembangkan oleh Riduwan (2009). Batas kelonggaran ketelitian yang ditorerir bagi setiap populasi tidak sama, seperti 1\%, 5\%, 10\% (Umar, 2002; Kriyantono, 2012) atau 15\% (Yamane, 1967; Riduwan, 2009). Batas kesalahan pengambilan sampel dalam penelitian ini adalah $15 \%$. Rumus untuk menghitung sampel adalah sebagai berikut:

$$
n=\frac{N}{\left(N * d^{2}+1\right)}
$$

Keterangan:

$n=$ Jumlah responden (orang)

$N=$ Jumlah petani yang tergabung dalam KTH (orang)

$d=$ Kelonggaran ketidaktelitian (15\%)

Berdasarkan Taro Yamane, maka diperoleh jumlah responden adalah 70 orang yang tersebar di 4 (empat) tingkat kemampuan kelompok yang berjumlah 312 kelompok tani hutan rakyat yang tersebar di 12 kecamatan Kabupaten Bogor. Selanjutnya, 70 responden atau 22 persen dari 312 kelompok tersebut dipilih sesuai keterwakilan kelompok secara proporsional dengan rincian responden dari kelompok Pemula (I) sebanyak 24 orang 
(=107x22\%), Lanjut (II) sebanyak 36 orang (=160x22\%), Madya (III) sebanyak 9 orang $(=42 \times 22 \%)$, dan Utama (IV) sebanyak 1 orang $(=3 \times 22 \%)$.

\section{HASIL DAN PEMBAHASAN}

\section{Aktor Dalam Arena Aksi Hutan Rakyat di Kabupaten Bogor}

Aktor dalam arena aksi ditentukan oleh tingkat peran masing-masing aktor dan pengaruhnya terhadap perilaku dan kinerja aktor lainnya. Konteks hubungan pengaruh mempengaruhi antar aktor dalam ruang arena aksi hutan rakyat diantaranya dalam konteks jual beli kayu, alih penguasaan lahan, dan perubahan pemanfaatan lahan. Konteks hubungan antar aktor tersebut dapat bersifat searah (mempengaruhi atau dipengaruhi) maupun saling mempengaruhi (pengaruh bolak-balik).

Berdasarkan hasil identifikasi terhadap aktor yang saling berinteraksi dan tingkat kebutuhan terhadap sistem pengelolaan hutan rakyat diperoleh 17 aktor, dengan rincian 10 pelaku utama dan 7 (tujuh) pelaku sekunder (Hardjanto et al., 2012). Kesepuluh pelaku utama yaitu: (1) petani pemilik; (2) petani penggarap; (3) buruh tani; (4) pedagang perantara (tengkulak); (5) penebang pohon, (6) pengusaha angkutan; (7) pemilik industri rental (sawmill); (8) pemilik industri barang jadi; 9) pemilik toko material; dan (10) konsumen dari Jakarta. Sedangkan tujuh pelaku sekunder, yaitu: (1) pemerintah desa; (2) BP3K (Balai Penyuluhan Pertanian; Perikanan dan Kehutanan); (3) UPT (Unit Pelaksana Teknis) Perkebunan dan Kehutanan; (4) BPDAS (Balai Pengelolaan Daerah Aliran Sungai) CiliwungCisadane; (5) Perum Perhutani KPH Bogor; (6) BPR (Bank Perkreditan Rakyat); (7) pemilik lahan dari luar desa (Jakarta dan Bogor). Selanjutnya ke-17 aktor ini dianalisis dengan menggunakan ISM.

\section{Hasil Pengolahan ISM}

Hasil analisis ISM terhadap peran 17 aktor berdasarkan hubungan kontekstual antar aktor dalam pengelolaan hutan rakyat diperoleh
7 (tujuh) aktor kunci sesuai tingkat pengaruh dan tingkat ketergantungan aktor yang berada di kuadran II, yaitu BP3K (E12), Pemilik lahan dari luar desa (E17), petani pemilik (E1), petani penggarap (E2), buruh tani (E3), pedagang perantara (tengkulak) (E4), dan penebang pohon (E5). 1 (satu) aktor kunci yang berada di kuadran IV, yaitu pengusaha industri penggergajian (rental) (E7) [Gambar 1]. Thompson (2011) menekankan bahwa stakeholder yang berada di kuadran III harus lebih aktif dilibatkan secara penuh dalam pengelolaan hutan berkelanjutan termasuk dalam mengevaluasi strategi baru. Kedelapan aktor kunci yang diperoleh dari dua kuadran tersebut di atas secara deskriptif dapat diuraikan isinya sebagai berikut.

(1) BP3K (E12). Pemerintah Kabupaten Bogor melalui BP3K (Balai Penyuluhan Pertanian, Perikanan, dan Kehutanan) atau suborganisasi dari BKP5K (Badan Ketahanan Pangan dan Pelaksana Penyuluhan Pertanian, Perikanan dan Kehutanan), mencanangkan kegiatan penyuluhan yang dapat menumbuhkan dan mengembangkan kelompok tani hutan, diantaranya melalui metode pelatihan secara kelompok. Pilihan metode ini memberi peluang adanya interaksi dua arah antara penyuluh dan petani. Pelatihan terhadap petani bisa meningkatkan pengetahuan, mempengaruhi sikap, dan memotivasi untuk berpartisipasi dalam kelompoknya. BP3K berperan dalam melakukan transfer pengetahuan dan teknologi kepada masyarakat lokal dan kelompok tani (poktan). BP3K berkepentingan terhadap tersedianya informasi dan teknologi pertanian, kehutanan, dan perikanan di masyarakat, produksi pertanian dan pendapatan masyarakat meningkat, diperolehnya masukan program bagi instansi pemerintah yang lebih implementatif dan terpadu berdasarkan analisis kebutuhan masyarakat lokal. BP3K berfungsi sebagai penyampai program-program pemerintah daerah kepada masyarakat hutan, misalnya menyampaikan program rehabilitasi lahan melalui program aksi berupa penanaman ataupun upaya konservasi tanah yang bertujuan untuk mencegah erosi, bencana banjir dan longsoran. 


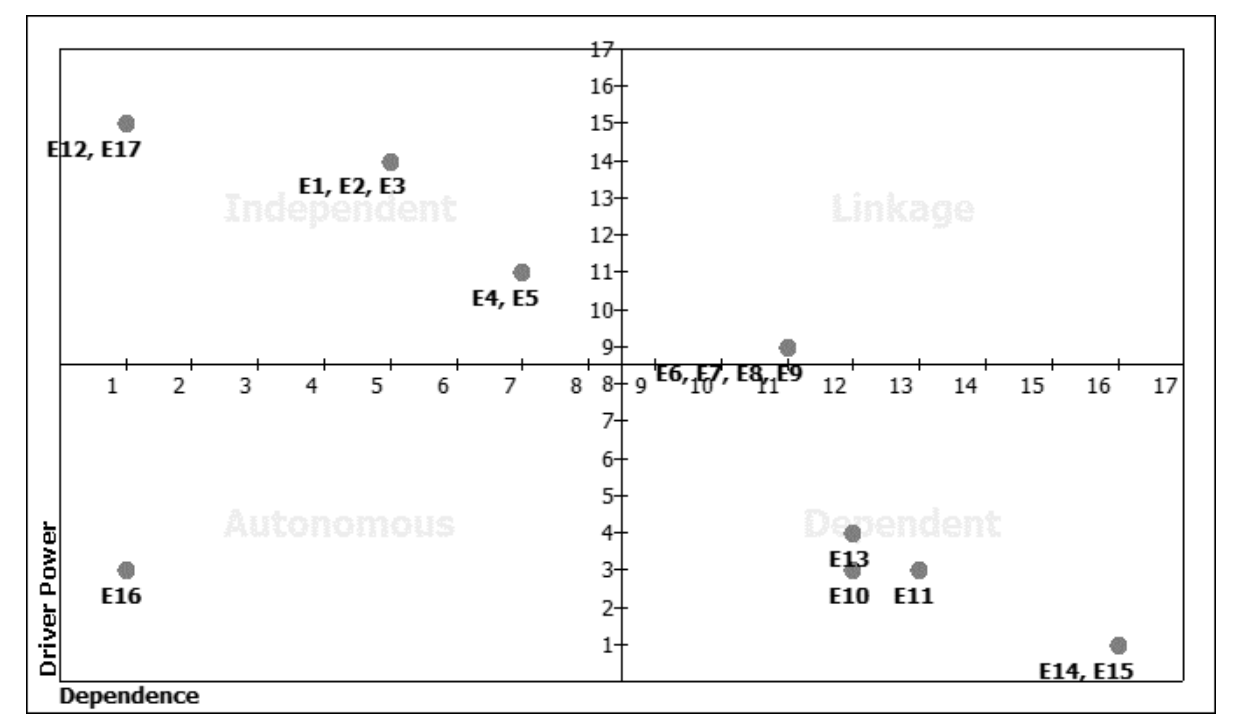

Gambar 1. Tingkat pengaruh dan ketergantungan aktor dalam pengelolaan hutan rakyat berdasarkan hasil ISM

Sumber: Hasil Penelitian, 2016

BP3K telah memiliki kelompok tani (poktan) binaan sebanyak 2,279 kelompok, 312 diantaranya merupakan kelompok tani hutan (KTH). Jumlah setiap tahunnya berubah-ubah, baik ada poktan yang baru terbentuk maupun poktan yang bubar. Tugas BP3K pasca pembentukan KTH adalah mengupayakan pengembangan kelompok tani dengan mendirikan sub-sub kelompok pendukung melalui kegiatan pengkaderan. Faktor kendala yang dihadapi BP3K dari kelompok tani hutan adalah faktor teknis seperti: (1) masih kurangnya pengetahuan petani dalam mengelola dan memanfaatkan lahan dengan kaidah-kaidah konservasi; (2) wawasan petani tentang konservasi masih rendah, sehingga belum terpikirkan bila terjadi bencana alam; (3) bagaimana memasarkan hasil lahan dan hutan. Dan faktor non teknis seperti: (1) wadah kelompok tani belum sesuai dengan fungsinya, dan kegiatan petani masih individual; (2) kelembagaan kelompok tani dan SDM petani yang masih perlu pembinaan dari pihak-pihak terkait; dan (3) Administrasi kegiatan kelompok belum tersusun secara sistematis.

Melalui kerja sama kelembagaan instansi pemerintah daerah antara UPT Perkebunan dan Kehutanan, BPDAS Ciliwung-Cisadane, dan Perum Perhutani KPH Bogor diharapkan berdampak kepada peningkatan kualitas penyuluhan di lapangan. Semakin berfungsinya BP3K maka program-program pemerintah dapat mudah disosialisasikan dan menampung program yang dibutuhkan oleh masyarakat. Pada tingkat teknis, kendala operasional lembaga BP3K adalah SDM (sumber daya manusia) tenaga penyuluh kehutanan yang sedikit, sehingga terhambatnya distribusi informasi dari tingkat pemerintah Kabupaten ke masyarakat pelaku kehutanan rakyat. Hasil penelitian Sukwika (2016) menyebutkan bahwa jumlah tenaga penyuluh kehutanan di Kabupaten Bogor sangat tidak mencukupi, yaitu satu tenaga penyuluh pemerintah ditugaskan di empat kecamatan. Idealnya, empat tenaga penyuluh per kecamatan.

(2) Petani pemilik (E1). Petani pemilik lahan di hutan rakyat menanami areal dengan jenis-jenis tanaman kayu seperti sengon (Paraserianthes falcataria), jabon (Anthocephalus cadamda), mahoni (Swietenia mahagoni), afrika (Maesopsis eminii), jati (Tectona grandis), dan campuran. Lahan hutan lebih banyak ditanami jenis tanaman sengon karena manfaat nilai ekonomi yang bisa diperoleh di dalamnya dan lain-lain. Jenis kayu sengon (istilah lokal: jeungjing) dipilih petani karena teknik budi dayanya telah dikuasai secara 
turun temurun. Tanaman sengon memiliki daur relatif pendek (5 hingga 8 tahun) dan memiliki pasar yang jelas. Petani biasanya menjual sengon dalam bentuk tegakan. Selain sengon, ada juga tanaman jenis tanaman tahunan seperti durian, manggis, karet, kelapa, petai, cengkeh dan lain-lain. Jenis tanaman lainnya yang ditanam adalah tanaman padi dan palawija.

Pengetahuan petani hutan rakyat diperoleh dari keluarga secara turun-temurun, pengalaman tetangga yang berhasil membudidayakan sengon, pemerintah pusat (Kementerian Kehutanan melalui BPDAS Ciliwung-Cisadane), Pemerintah Kabupaten Bogor (Penyuluhan-BP3K dan UPT Perkebunan Kehutanan), dan Perum Perhutani (Program KTH).

Petani pemilik lahan sangat berperan dalam pengambilan keputusan terhadap pengelolaan lahan hutan rakyat. Rata-rata kepemilikan lahan hutan rakyat per kepala keluarga satu sampai dua hektar. Keluarga petani memiliki peran yang dominan dalam memutuskan apakah lahan miliknya tetap dipertahankan sebagai hutan rakyat atau dipergunakan untuk jenis kegiatan usaha tani lain. Misalnya, sawah, ladang, atau empang.

(3) Pemilik lahan dari luar desa (E17). Kepemilikan lahan di kawasan hutan rakyat di Kabupaten Bogor tidak hanya dimiliki oleh masyarakat lokal, tapi juga dari masyarakat yang tinggal di luar kawasan hutan rakyat. Masyarakat luar pemilik lahan yang telah menguasai lahan lebih dari 60 persen di hutan rakyat (Sukwika, 2016). Kelompok masyarakat luar pemilik lahan di hutan rakyat ini memilki peran dalam pengambilan keputusan terhadap lahan yang dimilikinya. Apakah dibiarkan tidak dimanfaatkan (guntai), diperuntukan untuk perkebunan, atau membangun rumah, infrastruktur dan sarana lainnya.

Sebagian besar, pemilik lahan hutan rakyat yang tinggal di luar desa membiarkan lahannya guntai. Ada juga pemilik lahan bekerjasama dengan penggarap setempat mengelola lahan. Adapun jenis tanaman yang diusakan adalah tanaman keras seperti kayu sengon dan jati, buah-buahan dan tanaman tahunan seperti palawija. Kerja sama ini sekaligus untuk menjaga aset lahan si pemilik.

(4) Petani penggarap (E2). Kelompok petani penggarap berkepentingan terhadap lahan yang dikuasainya, baik lahan milik keluarga, sewa dan/atau pinjam dari pihak lain. Kelompok tani penggarap berkepentingan terhadap lahan yang dimiliki oleh masyarakat yang tinggal di luar kawasan dan tidak memanfaatkan sumber daya lahannya.

Lahan yang dimanfaatkan oleh kelompok petani penggarap (milik masyarakat luar desa) oleh penyuluh pemerintah dijadikan sebagai sasaran lokasi untuk perbaikan kondisi lingkungan lokal. Selama ini, penyuluh kesulitan untuk berkoordinasi dengan pemilik yang lahannya dibiarkan tidak produktif, sehingga program pemerintah terkait rehabilitasi lahan terhadap lahan tidur (guntai) di Kabupaten Bogor kurang berjalan baik.

(5) Buruh tani (E3). Jenis pekerjaan buruh tani di kawasan hutan rakyat, secara proporsi, merupakan mata pencaharian yang paling tinggi setelah petani. Buruh tani di hutan rakyat umumnya sebagai petani, yang diantaranya ada juga yang memiliki lahan sendiri, biasanya kurang dari 0.10 hektar. Petani menyambi sebagai buruh tani di tempat lain, setelah petani tersebut selesai dari ladangnya.

Keberadaan kelompok masyarakat ini menjadi pendorong pelaksanaan kegiatan agroforestri di kawasan hutan rakyat. Buruh tani sering dilibatkan karena kekurangan tenagakerja dari dalam keluarga. Jenis kegiatan yang dilakukan oleh buruh tani mulai dari pembukaan lahan, penanaman, dan pemanenan. Biaya di hutan rakyat sesuai pengakuan masyarakat sebesar Rp 25,000 sampai dengan Rp 35,000 per hari. Nilai ini masih rendah jika dibandingkan dengan standar Badan Pusat Statistik (BPS) tahun 2016 yaitu upah nominal harian buruh tani nasional adalah sebesar Rp 47,731 per hari. Curahan tenaga kerja yang berperan di hutan rakyat berasal dari anggota keluarga dan buruh tani.

(6) Pedagang perantara (E4). Bagi petani, keberadaan pedagang perantara atau disebut dengan istilah Tengkulak merupakan 
mitra strategis dalam tata niaga kayu hutan rakyat. Interaksi petani kepada tengkulak (98\% dari 70 responden) lebih sering dibandingkan frekuensi interaksi ke koperasi (27\%) atau industri penggergajian (rental/sawmill) pedagang kayu (eceran), dan pembuat perabotan kayu (45\%). Tengkulak selain sebagai mitra dagang juga berfungsi sebagai 'lembaga perkreditan' bagi petani. Pedagang perantara (tengkulak) umumnya meminjam modal dari pemilik industri, selanjutnya pemilik industri meminjam modal dari toko material dan/atau pinjaman Bank Perkreditan Rakyat (BPR).

Petani lebih memilih menjual kayunya kepada tengkulak, alasanya lebih praktis, cepat menghasilkan uang, tidak repot mengurus perijinan, semua jenis kayu dapat dijual, sampah penebangan seluruhnya diangkut oleh pembeli sehingga lahan bersih dan siap untuk ditanam kembali. Meskipun posisi tawar tengkulak lebih kuat daripada petani, namun diakui bahwa petani $(86 \%)$ selalu mendapatkan harga kesepakatan tanpa ada unsur paksaan dari tengkulak, sekalipun dalam posisi tebang butuh.

Terkait pemasaran kayu, petani tidak perlu bersusah payah memasarkan kayu mereka, karena pembeli yang biasanya merupakan pedagang pengumpul akan mendatangi penjual untuk melakukan transaksi setelah sebelumnya melihat kondisi pohon yang akan dijual. Harga jual tegakan kayu rakyat tidak sama antara satu lokasi dengan lokasi lainnya. Beberapa faktor yang mempengaruhi harga jual kayu adalah jauh tidaknya lokasi lahan dari jalan, sulit atau tidaknya sarana transportasi menuju lokasi hutan rakyat, serta diameter dan kualitas kayu. Proses administrasi seperti kelengkapan dokumen Surat Keterangan Sah Hasil Hutan (SKSHH) dilakukan oleh pembeli.

Ruang lingkup tata niaga pedagang perantara ini sangat luas dan berbasis jejaring kerja (networking). Pedagang perantara ini memiliki modal relatif besar dan memiliki tempat semacam TPK (tempat penampungan kayu). Bahkan beberapa pedagang ini biasanya meminjamkan modal kepada penebang, sehingga mereka dapat langsung mendapatkan kayu sengon dalam jumlah besar untuk dikirimkan langsung ke industri pengolahan kayu. Pemilik Depo terkadang tidak hanya mempunyai tempat penimbunan kayu, akan tetapi mereka juga memiliki sawmill kecil sehingga dapat langsung memenuhi permintaan industri dalam bentuk balken (kayu bulat yang sudah diubah menjadi bentuk papan) atau yang lain. Pedagang perantara juga ada yang bertidak sebagai suplier (pedagang pemasok industri). Supplier memperoleh bahan baku dari pemilik depo dan telah memiliki kontrak kerja dengan industri pengolahan kayu, sesuai permintaan industri berdasarkan kualitas (ukuran diameter dan mutu tertentu) dan kepastian jumlah kayu sengon yang siap dipasok ke industri.

(7) Penebang pohon (E5). Kelompok masyarakat penebang pohon memiliki profesi sebagai pedagang perantara (tengkulak). Ketika berprofesi sebagai tengkulak, penebang menggunakan akses langsung membeli sengon pada lahan petani berupa tegakan seperti pohon sengon (jeungjing). Sehingga upah menebang, bongkar muat dan transportasi ke Depo menjadi beban penebang. Penebang membeli pohon sengon petani bisa dalam jumlah banyak atau satu dua pohon saja, karena petani biasanya menjual berdasarkan kebutuhan. Jika petani membutuhkan jasa tebang pohon dikenakan biaya sebesar 200 ribu perhari dan biasanya dilakukan oleh 3 orang penebang.

(8) Pemilik industri rental (E7). Pengusahaan hutan rakyat telah mendorong berkembangnya usaha jasa dalam bidang penggergajian kayu atau disebut dengan istilah rental. Terdapat sebanyak 146 unit industri primer hasil hutan rakyat yang tersebar di 25 kecamatan dan sedikitnya 50 unit armada transportasi yang beroperasi setiap hari. Industri rental rata-rata menerima kayu langsung dari petani 1 mobil, sedangkan dari tengkulak minimal 3 mobil. Jenis kayu-kayu yang diangkut ke rental seperti kayu sengon, afrika, kapuk, dan karet. Biaya angkutan antara 100 ribu sampai 500 ribu rupiah sesuai jarak. Biaya bongkar muat 100 ribu sampai 300 ribu rupiah dilakukan oleh tiga sampai enam orang.

Produk yang biasanya dihasilkan oleh industri rental biasanya berupa papan, balok, 
kaso, tiang, palang, pallet kaca, dan bahan sofa bangku. Sangat jarang industri primer rental yang memproduksi lembaran kayu lapis (vinir), lapis dalam kayu lapis (bare core), laminating kayu lamina (joint finger), papan blok (block board) hingga kayu lapis. Pengusahaan hutan rakyat juga telah mendorong tumbuhnya unit usaha kerajinan (home industry) dengan bahan baku kayu dengan produk berupa kerajinan kayu dan seni handycraft. Pengusahaan hutan rakyat juga merupakan penopang bahan baku bagi kelangsungan pengusaha/pengrajin furniture. Konsumen yang mengambil hasil kayu olahan dari industri rental umunya berasal dari pemilik industri barang jadi dan toko material, bahkan ada juga konsumen luar Kabupaten Bogor seperti Jakarta.

Industri rental yang terdapat di Kabupaten Bogor biasanya memperoleh bahan baku dari pedagang perantara (depo atau suplier), bahkan ada yang mendapatkan langsung dari petani. Industri rental sering ditemukan di sekitar dekat zona-zona hutan rakyat. Tersebar berkelompok secara sporadis berdiri di sisi-sisi jalan raya. Kapasitas produksi antara 500 hingga 1,000 $\mathrm{m}^{3}$ per tahun. Kepemilikan tempat usaha industri sebagian besar didirikan/menggunakan lahan yang diperoleh secara sewa/kontrak. Marjin profit besar (tidak proporsional), kemampuan teknologi industri rental rendah, menghasilkan banyak limbah (belum dimanfaatkan secara efisien), potongan kayu bulat ditumpuk di sisi jalan, sharing terhadap pemeliharaan kualitas lingkungan rendah, dan komitmen pengusaha terhadap peningkatan kesejahteraan petani rendah.

Terkait pengelolaan lingkungan, keberadaan industri primer ini juga dapat menimbulkan dampak negatif. Keberadaan industri yang tidak terkelola dengan baik akan menyebabkan tidak sejalannya laju penggunaan bahan baku industri dengan laju pembangunan hutan rakyat. Kebutuhan bahan baku industri akan menjadi kontra produktif dengan upayaupaya pengelolaan lingkungan di Kabupaten Bogor terutama karena keberadaan Kabupaten Bogor sebagai daerah hulu dari 6 daerah aliran sungai (DAS) yaitu DAS Ciliwung, Kali Bekasi,
Cisadane, Citarum Hilir, Cidurian dan Cimanceuri.

\section{Struktur Hierarki Aktor}

Keluaran model ISM untuk klasifikasi sub-elemen pendukung berdasarkan tingkat driver power (DP) dan tingkat dependency (D) [Gambar 1], menunjukkan bahwa ada satu subelemen pendukung pengembangan yang tidak berkaitan dengan sistem (sektor I Autonomous = 0) yaitu sub-elemen Bank Perkreditan rakyat. Sub-elemen (E) E6, E7, E8, dan E9 berada pada sektor III (Linkage) sehingga harus dikaji secara cermat dan hati-hati karena sifat hubungannya yang tidak stabil tapi sangat berkaitan sekaligus berdampak pada sub-elemen lainnya terutama pada sub-elemen sektor II (Dependent). Pemilik industri rental (E7) sangat berperan terhadap posisi supply demand kayu hutan rakyat di Kabupaten Bogor. Bagi petani, industri rental merupakan pasar terakhir yang sering menampung hasil kayunya. Tentunya ini mendorong petani mengubah prilaku dalam pemilihan jenis tanaman kayu yang dibudidayakan. Berdasarkan jalur rantai usaha atau saluran pemasaran (SP) hutan rakyat di Kabupaten Bogor, konsumen terakhir umumnya pedagang perantara (tengkulak) dan pasar terakhir adalah industri rental. Pada umumnya sub-elemen merupakan peubah tidak bebas (Sektor III) sangat tergantung dari input dan tindakan yang diberikan pada sistem dan peubah bebas (Sektor I).

Keluaran model ISM menunjukkan struktur hierarki hubungan antar sub-elemen pendukung terdiri dari 7 level [Gambar 2] dengan asumsi hubungannya bahwa sub-elemen pendukung yang satu mempengaruhi manfaat sub-elemen pendukung yang lain. Secara struktural, terdapat 7 aktor kunci yang berasal dari level 5 hingga 7. Dari ketujuh aktor kunci tersebut, aktor paling domiman dalam pengelolaan hutan rakyat berkelanjutan di Kabupaten Bogor adalah BP3K (E12) dan Pemilik lahan dari luar desa (E17) menempati level tertinggi (level 7) dengan total DP (driven power) terbesar. Di mana posisinya memiliki daya pendorong tertinggi sehingga sub-elemen 
BP3K ini merupakan sub-elemen kunci dari elemen perubahan yang dimungkinkan. Hierarki model mengartikan bahwa sub-elemen pada suatu level didukung oleh terpenuhinya subelemen pada level dibawahnya. Keluaran model menunjukkan kedudukan sub-elemen lembaga penyuluhan ini besar perannya dalam memotivasi dan mengajak masyarakat berpartisipasi mengelola hutan rakyat lestari.
Peran masyarakat lokal dan kinerja program pemerintah sangat ditentukan oleh BP3K ini. Di samping kelompok BP3K (Level 6), juga terdapat aktor kunci lainnya yaitu di level 5 ada Petani pemilik lahan (E1), Petani penggarap (E2), dan Buruh tani (E3). Di level 4 ada Pedagang perantara (E4), dan Penebang pohon (E5).
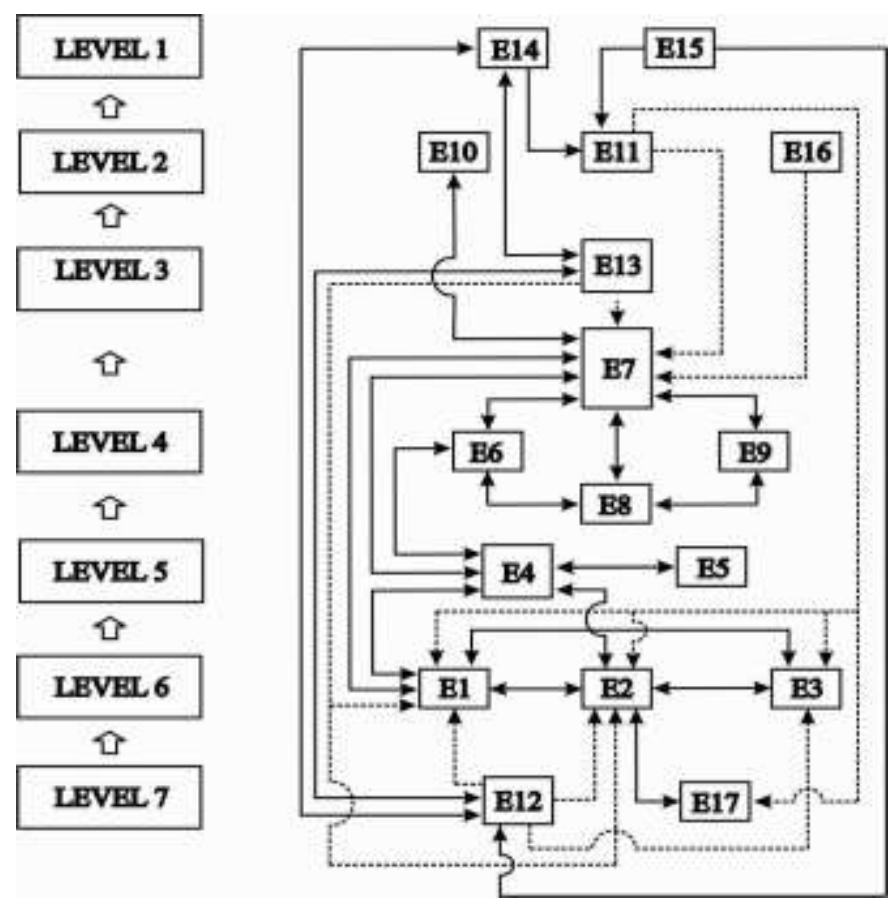

Keterangan:

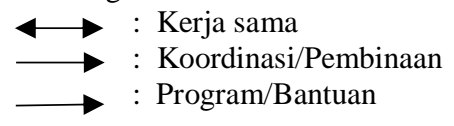

E1. Petani pemilik

E2. Petani penggarap

E3. Buruh tani

E4. Pedagang perantara

E5. Penebang pohon

E6. Pengusaha angkutan

E7. Pemilik industri rental

E8. Pemilik industri barang jadi

E9. Pemilik toko material

E10. Konsumen luar Kab. Bogor

E11. Pemerintah Desa

E12. BP3K

E13. UPT Perkebunan dan Kehutanan

E14. BPDAS Ciliwung-Cisadane

E15. Perhutani KPH Bogor

E16. Bank Perkreditan Rakyat

E17. Pemilik lahan dari luar Desa

Gambar 2. Struktur hierarki sub-elemen kelembagaan pengelolaan hutan rakyat berdasarkan aktor yang berpengaruh hasil ISM

Sumber: Hasil Penelitian, 2016

Tabel 1 Kebutuhan hidup layak (KHL) petani hutan rakyat

\begin{tabular}{|c|c|c|c|c|c|c|c|c|}
\hline No. & $\begin{array}{l}\text { Jenis } \\
\text { Pengeluaran }\end{array}$ & $\%$ & $\begin{array}{l}\text { Beras } \\
(\mathrm{kg})\end{array}$ & $\begin{array}{l}\text { Harga } \\
\text { beras*) } \\
(\mathrm{Rp} / \mathrm{kg})\end{array}$ & $\begin{array}{l}\text { Pengeluaran } \\
\text { (Rp./kap/th) }\end{array}$ & $\begin{array}{l}\text { Jumlah } \\
\text { anggota } \\
\text { keluarga }\end{array}$ & $\begin{array}{l}\text { Kebutuhan } \\
\text { (Rp/KK/th) }\end{array}$ & $\begin{array}{l}\text { Kebutuhan } \\
\text { (Rp/KK/bl) }\end{array}$ \\
\hline$a$ & $b$ & $c$ & $d$ & $e$ & $f$ & $g$ & $h$ & $i$ \\
\hline & & $\% d$ & & & $d x e$ & & $e x f$ & $e / 12$ \\
\hline 1 & KFM & 100 & 320 & 8,500 & $2,720,000$ & 4 & $10,880,000$ & 907,000 \\
\hline 2 & $\begin{array}{l}\text { Pendidikan } \\
\text { (SD s/d SMA) }\end{array}$ & 50 & 160 & 8,500 & $1,360,000$ & 4 & $5,440,000$ & 453,000 \\
\hline 3 & Kesehatan & 50 & 160 & 8,500 & $1,360,000$ & 4 & $5,440,000$ & 453,000 \\
\hline 4 & $\begin{array}{l}\text { Sosial, } \\
\text { Tabungan, dll. }\end{array}$ & 50 & 160 & 8,500 & $1,360,000$ & 4 & $5,440,000$ & 453,000 \\
\hline 5 & KHL & 250 & 800 & 8,500 & $6,800,000$ & 4 & $27,200,000$ & $2,267,000$ \\
\hline
\end{tabular}

Catatan : *) Harga rataan beras konsumsi (medium) di Kabupaten Bogor 2016

Sumber: Hasil Penelitian, 2016 


\section{Model Kelembagaan Modal Usaha}

Kehidupan petani hutan rakyat di Kabupaten Bogor masih dihadapkan kepada perbedaan pola pendapatan dan pengeluaran petani. Di mana, pendapatan petani hanya diterima pada saat musim panen saja, sedangkan pengeluaran petani dikeluarkan setiap saat hingga musim panen tiba. Responden petani sebagian besar (91\%) mengakui bahwa total pengeluaran bulanan rumah tangga selalu lebih besar dari total pendapatannya. Cara petani yang sering dilakukan untuk mengatasi kondisi "besar pasak daripada tiang" adalah petani melakukan pinjaman utang kepada tetangga, tengkulak, atau bank keliling semacam rentenir. Petani menawarkan diri menjadi buruh tani atau penggarap. Ada juga petani yang menjual pohon kayu hanya beberapa batang saja seperti jenis kayu sengon, afrika, atau jati kepada tengkulak. Berdasarkan Tabel 1, pendapatan rumah tangga petani ini masih di bawah kebutuhan fisik minimum (KFM) untuk memenuhi kebutuhan pokok konsumsi sebesar Rp 10,880,000 per tahun atau Rp 907,000 per bulan. Pendapatan tersebut juga masih di bawah UMR Provinsi Jawa Barat tahun 2016 Rp 2,147,395 per bulan atau upah mininum Kabupaten Bogor tahun 2016 sebesar $\mathrm{Rp}$ 2,960,325 per bulan, apalagi jika dibandingkan dengan UMK Bogor tahun 2018 sebesar $\operatorname{Rp~3,483,667~per~bulan.~}$ Kebutuhan hidup layak (KHL) untuk keluarga dengan 4 orang anggota sebesar Rp 27,200,000/tahun atau Rp 2,267,000 per bulan. Artinya, petani hutan rakyat di Kabupaten Bogor masih berkategori berpendapatan rendah, ratarata total pendapatan rumah tangga petani hutan rakyat sekitar $25 \%$ dari total pengeluaran keluarga.

Kebutuhan yang terus meningkat dan beragam menjadi salah satu faktor pengambilan keputusan keluarga petani dalam mempercepat jadwal penebangan. Berdasarkan hasil kuesioner penelitian di lapangan, bahwa alasan dominan petani hutan rakyat melakukan tebang butuh, yaitu: serangan hama dan penyakit (HMA) oleh hewan, jamur (parasitoid), ganggang, virus dan/atau bakteri; konsumsi keperluan keluarga (KON) untuk memenuhi kebutuhan sehari-hari keluarga petani, perayaan keluarga, kesehatan, dan bayar utang; kebutuhan hari raya (HRY) untuk membeli keperluan pangan dan sandang; biaya penanaman non-kayu (TMN) untuk pembelian bibit, pupuk, penanaman, dan buruh tani; renovasi rumah (RMH) selain untuk keperluan renovasi rumah dan membuat bangunan lain yang memerlukan bahan materian kayu; dan biaya sekolah anak (SKL) untuk keperluan pebelian buku, pembayaran iuran sekolah, dan kegiatan ektrakulikuler lainnya.

Pada Gambar 3 terlihat bahwa alasan petani menebang kayu saat membutuhkan karena kebutuhan konsumtif untuk keluarga petani, seperti membeli kendaraan roda dua, pakaian, dan non-pangan lainnya. Alasan menebang kayu untuk keperluan biaya sekolah anak menempati urutan kedua. Tanaman kayu yang terindikasi ada serangan hama dan penyakit juga menjadi alasan petani untuk menebang kayunya. Jenis hama yang sering menyerang tanaman kayu sengon pada usia tiga tahun adalah hama ulat (larva kumbang) serendang (Xystrocera festiva) atau boktor/penggerek batang atau istilah lokalnya uter-uter. Jenis penyakit yang menjangkit tanaman sengon saat usia masih satu sanpai dengan dua tahun adalah jamur Uromycladium tepperianum yang menyebabkan penyakit karat puru.

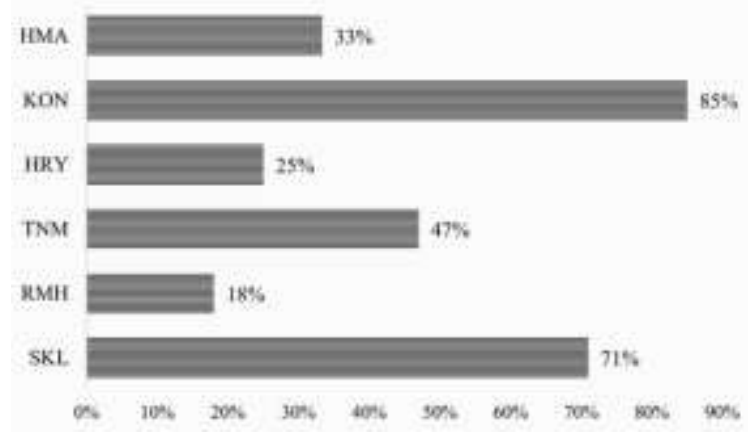

Gambar 3. Alasan tebang butuh petani hutan rakyat Sumber: Hasil Penelitian, 2016

Keterangan:

HMA=Serangan hama penyakit; KON=Konsumsi keluarga; HRY=Keperluan hari raya; TMN=Biaya penanaman non-kayu; $\mathrm{RMH}=$ Renovasi rumah; $\mathrm{SKL}=$ Biaya sekolah anak 


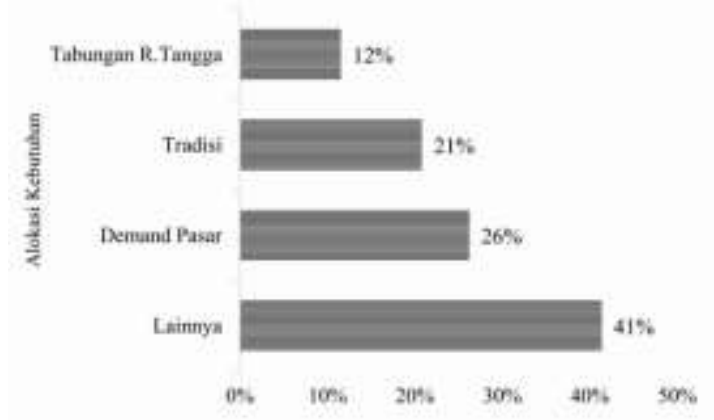

Gambar 4. Alokasi petani menanam kayu hutan rakyat

Sumber: Hasil Penelitian, 2016

Di kabupaten Bogor, tebang butuh (slash for cash) yang dilakukan oleh petani tidak lagi digambarkan sebagai sebuah kondisi di mana kebutuhan keluarga petani tidak pernah terduga, sebaliknya justru sebagian petani berpendapat bahwa kayu yang ditanam di hutan rakyatnya sebagai tabungan untuk dapat diambil sewaktuwaktu. Bagi masyarakat yang tinggal di sekitar kawasan hutan, menanam kayu adalah identitas budaya masyarakat desa hutan, sekaligus tradisi yang sudah menjadi budaya secara turun temurun.

Hutan rakyat terus mengalami perkembangan produksi kayu sebagai dampak dari hasil pola interaksi yang terbentuk di kawasan hutan rakyat. Di mana, diantaranya terdapat peran dari aktor pelaku ekonomi yaitu industri perkayuan primer atau rental. Kondisi ini berhasil mempengaruhi pola pengambilan keputusan petani dalam menentukan jenis kayu yang ditanam sesuai permintaan pasar. Petani juga mengalokasikan menanam kayu untuk kebutuhan lainnya seperti alasan perbaikan lingkungan, memperoleh insentif untuk setiap tegakan yang ditanam, bentuk sikap kooperatif terhadap bantuan pihak luar, dan lain-lain. Alokasi petani menanam kayu hutan rakyat disajikan pada Gambar 4.

Jika dikaitkan dengan Gambar 2 "Struktur hierarki sub-elemen kelembagaan pengelolaan hutan rakyat berdasarkan aktor yang berpengaruh hasil ISM", persoalan pemodalan hampir dihadapi oleh semua aktor di hutan rakyat. Persoalan pembiayaan ragam kebutuhan keluarga petani (E1, E2) menjadikan keputusan "tebang butuh" sebagai pilihan. Tengkulak (E4) sebagai aktor price maker memerlukan dana segar selain untuk membayar kayu petani, juga untuk angkutan dan bongkar muat, tengkulak biasanya meminjam ke rental yang akan dikirimi kayu. Kebutuhan dana operasional rental (E7) berasal dari dari BPR (E16) seperti BRI atau lembaga keuangan mikro, dan toko material (E9), kadangkala bank keliling (rentenir).

Pada kondisi di atas, model kelembagaan modal usaha dapat dirancang dengan mengatur aturan main organisasi yang melibatkan lima aktor utama yaitu E1, E2, E4, E7, dan E16. Petani (E1, E2) menjadikan tanaman kayu hutan rakyat sebagai tabungan yang dapat diambil sewaktu-waktu, Oleh karena itu, keberadaan lembaga penyimpan tabungan kayu hutan rakyat menjadi penting. BPR (E16) kurang diakses oleh petani hutan rakyat di Kabupaten Bogor, oleh karena itu, lembaga keuangan yang memungkinkan bisa berperan menyediakan pembiayaan untuk kebutuhan keluarga petani adalah lembaga keuangan mikro (LKM) (Ashari, 2006; Susila, 2007) dan/atau koperasi petani hutan rakyat (KPHR) (Sukisman dan Setiawan, 2011). Dalam skema LKM atau KPHR, pohon dimungkinkan menjadi agunan. Kedua lembaga ini dapat mengambil sebagian tabungan pada hutan rakyat khususnya untuk kebutuhan skala kecil yang tidak terduga.

Keberadaan lembaga ini dapat mengurangi ruang gerak dari peran tengkulak sebagai price maker. Sebaliknya, peran tengkulak (E4) dapat menjadi bagian dari pelaku ekonomi dalam organisasi ini, sekaligus mengubah posisi dari price maker menjadi price order melalui skema pelelangan kayu (sale by auction). Sedangkan rental (E7) yang akan memanfaatkan kayu harus menjadi anggota pengguna hasil kayu rakyat. Alternatif lain adalah memanfaatkan skema "kredit tunda tebang" atau dana pinjaman yang memungkinkan para petani tidak menebang ketika mereka sedang membutuhkan (uang), tetapi menunggu sampai pohonnya lebih besar sehingga nilai komersialnya lebih besar yang diinisiasi BLU (Badan Layanan Umum) KLHK RI bisa menjadi salah satu bagian aturan main organisasi model kelembagaan modal usaha. 
Pada sistem pemasaran dan pengolahan, aktor yang paling dominan terlibat pada saluran pemasaran (SP) di kawasan hutan rakyat petani (E1), tengkulak (E4), industri rental (E7) dan toko material (E9) atau disebut dengan SP1. Pada SP2 terdiri atas petani, industri rental dan toko material. Sedangkan aktor yang berada di SP3 adalah petani, tengkulak, industri rental dan industri barang jadi (E8) dan/atau konsumen dari luar daerah (E10). Berdasarkan Gambar 1, secara kualitatif, model kelembagaan modal usaha terhadap petani pemilik lahan, petani penggarap, dan tengkulak dapat digambarkan dalam hubungan fungsi sebagai berikut:

(1) $\mathrm{E} 1=\mathrm{f}(\mathrm{E} 2, \mathrm{E} 3, \mathrm{E} 4, \mathrm{E} 7, \mathrm{E} 12, \mathrm{E} 13, \mathrm{E} 16)$

(2) $\mathrm{E} 2=\mathrm{f}(\mathrm{E} 1, \mathrm{E} 3, \mathrm{E} 4, \mathrm{E} 12, \mathrm{E} 13, \mathrm{E} 16)$

(3) $\mathrm{E} 4=\mathrm{f}(\mathrm{E} 1, \mathrm{E} 2, \mathrm{E} 5, \mathrm{E} 6, \mathrm{E} 7)$

Dimana:

E1 = Petani pemilik

E2 = Petani penggarap

E3 = Buruh tani

$\mathrm{E} 4=$ Pedagang perantara

E5 = Penebang pohon

E6 = Pengusaha angkutan

E7 = Pemilik industri rental

$\mathrm{E} 12=\mathrm{BP} 3 \mathrm{~K}$

E13 = UPT Perkebunan dan Kehutanan

E16 $=$ Bank Perkreditan Rakyat

\section{Model Kelembagaan Penanganan Pemborosan Sumber daya}

Berdasarkan hasil ISM, posisi industri rental berada dalam kuadran Linkage di mana aktivitasnya bisa berimplikasi positif atau negatif terhadap sub elemen lain. Industri rental ini bergerak diusaha lanjutan hasil hutan. Produk utama dari kegiatan industri primer hasil hutan kayu adalah sawn timber, dapat berupa papan, kaso, balok dan lainnya. Produk limbah yang dihasilkan dari hasil industri primer hasil hutan kayu adalah berupa sempengan (limbah kayu masih berbentuk kayu solid) ataupun dalam bentuk serbuk kayu. Untuk produk industri berupa limbah, maka akan dikembangkan usaha hasil hutan lainnya berupa budi daya jamur dan pembuatan briket yang memanfaatkan serbuk gergaji ataupun kayu serpihan. Peluang-peluang pemanfaatan hasil utama dari industri primer hasil hutan kayu tersebut menjadi sub unit usaha tersendiri di bawah pengelolaan unit manajemen koperasi.

Pembentukan model kelembagaan penanganan pemborosan sumber daya bertujuan mengatasi masalah pemborosan sumber daya oleh industri rental. Pembentukan organisasi dan aturan main melibatkan banyak aktor yang berperan, yaitu: petani (E1, E2) yang berperan di usaha hutan rakyat, pemilik industri rental (E7) yang berperan di industri primer hasil hutan kayu (IPHHK), Dinas Koperasi UKM Perindustrian dan Perdagangan Kabupaten Bogor membentuk unit usaha koperasi hutan rakyat, dan berkoordinasi dengan BP3K (E12) dan UPT Perkebunan-Kehutanan (E12) atau pemerintah desa (E11) setempat. Dengan adanya sub unit usaha lanjutan, maka Unit usaha Koperasi Hutan Rakyat akan mewadahi sekurangnya 3 Sub Unit Usaha, yaitu: (1) sub unit usaha hutan rakyat; (2) sub unit usaha IPHHK (Izin Usaha Pemanfaatan Hasil Hutan Kayu), dan (3) sub unit usaha lanjutan. Secara kualitatif, model kelembagaan penanganan pemborosan sumber daya dapat digambarkan dalam hubungan fungsi sebagai berikut:

$\mathrm{E} 7=\mathrm{f}(\mathrm{E} 1, \mathrm{E} 4, \mathrm{E} 6, \mathrm{E} 8, \mathrm{E} 9, \mathrm{E} 11, \mathrm{E} 13, \mathrm{E} 16)$

Dimana:

E1 = Petani pemilik

E4 = Pedagang perantara

E6 = Pengusaha angkutan

E7 = Pemilik industri rental

E8 = Pemilik industri barang jadi

E9 = Pemilik toko material

E11 = Pemerintah Desa

E13 = UPT Perkebunan dan Kehutanan

E16 = Bank Perkreditan Rakyat

\section{Model Kelembagaan Koordinasi}

Pada pelaku hutan rakyat (HR) berbeda dengan pelaku hutan kemasyarakatan (HKm), di mana Perhutani KPH Bogor (E15) dan BPDAS Ciliwung-Cisadane (E14) tidak bisa melakukan koordinasi langsung dengan masyarakat pelaku hutan rakyat. Sebaliknya, koordinasi langsung dengan pelaku hutan rakyat bisa dilakukan oleh BP3K (E12), dan UPT Perkebunan-Kehutanan 
(E13). Model kelembagaan koordinasi dapat dirancang dengan melibatkan aktor dari E13, E14, dan E15 yang dimotori oleh E12. Secara administrasi kewilayahan, model kelembagaan koordinasi ini tentunya diketahui oleh pemerintahan desa (E11) dan kecamatan, pemerintah daerah (Kabupaten Bogor) dan pemerintah pusat (Kementerian Lingkungan Hidup dan Kehutanan).

Dalam model kelembagaan koordinasi ini, perlu dirancang sebuah pelayanan bisnis hutan rakyat di bawah otoritas bupati Kabupaten Bogor. Konsep bisnis hutan rakyat ini melayani keperluan-keperluan hutan rakyat, seperti penyediaan bibit, pupuk, angkutan, bantuan teknis, pendanaan, dan lain-lain. Aktifitas jual beli hasil hutan kayu yang dipergunakan adalah skema pembelian secara lelang (auction buying). Model kualitatif kelembagaan kelembagaan koordinasi berdasarkan hasil ISM dapat digambarkan dalam hubungan fungsi sebagai berikut:

$$
\mathrm{E} 12=\mathrm{f}(\mathrm{E} 13, \mathrm{E} 14, \mathrm{E} 15)
$$

Dimana:

$$
\begin{aligned}
& \text { E12 }=\text { BP3K } \\
& \text { E13 }=\text { UPT Perkebunan dan Kehutanan } \\
& \text { E14 }=\text { BPDAS Ciliwung-Cisadane } \\
& \text { E15 = Perhutani KPH Bogor }
\end{aligned}
$$

\section{Aksi Bersama (collective action)}

Kondisi hutan kritis di Kabupaten Bogor sangat tinggi yaitu mencapai sekitar 20,000 hektar, kerusakan sebagian besar berada di hutan negara. Hal ini dinilai sebagai akibat atas berubahnya lansekap lahan hutan, berkurangnya penutupan hutan, berubahnya lahan bervegetasi menjadi bangunan atau permukiman, dan rusaknya lingkungan di hulu atau di sekitar sumber-sumber mata air. Berbeda penanganannya dengan di hutan rakyat, penanganan rehabilitasi hutan kritis milik negara sangat lambat di Kabupaten Bogor. Upayaupaya yang diperlukan adalah pemerintah perlu melakukan aksi bersama melibatkan masyarakat pelaku hutan. Skema insentif berupa pembangunan hutan rakyat dapat dilakukan, yaitu lahan-lahan kritis di dalam hutan milik
Negara (Persson dan Prowse, 2017). Di mana skema pengelolaannya menjadi hutan rakyat melalui program penghijauan. Skema insentif tersebut dimungkinkan oleh Permenhut No. P.9/Menhut-II/2013 tentang Tata Cara Pelaksanaan, Kegiatan Pendukung dan Pemberian Insentif Kegiatan Rehabilitasi Hutan dan Lahan, pasal (10) penghijauan sebagaimana dimaksud pada ayat (1) bertujuan menjaga dan meningkatkan fungsi perlindungan tata air dan pencegahan bencana alam banjir, longsor, dan/atau untuk meningkatkan produktivitas lahan. Selama ini, pemerintah secara formal mengakui aturan informal yang ada dalam masyarakat dan menyerahkan pelaksanaan aturan tersebut kepada masyarakat hutan rakyat. Keuntungan kebijakan tersebut dapat mengurangi biaya transaksi pengelolaan hutan. Keuntungan lainnya adalah dapat memberikan dampak (outcomes) berupa (1) meningkatnya kesadaran masyarakat terhadap pentingnya hutan; (2) meningkatnya partisipasi masyarakat dan aksi kolektif dalam pengelolaan hutan; dan (3) meningkatnya pendapatan masyarakat (Kasper dan Streit, 1998; Okumu dan Muchapondwa, 2017).

Menyikapi kondisi di atas maka, Dinas Pertanian dan Kehutanan Kabupaten Bogor bersama BP3K dapat menggelar program Rehabilitasi Hutan dan Lahan di lahan-lahan kritis baik di hutan negara dan hutan rakyat. Melalui program aksi ini dapat mendorong tumbuhnya kesadaran dan persepsi kelompok tani hutan. Aksi bersama yang dibutuhkan diantaranya dengan mempertahankan penutupan hutan yang masih baik dan melakukan penanaman lahan yang kosong/terbuka. Persoalan hutan di Kabupaten Bogor tidak terbatas pada lahan-lahan kritis negara, maraknya kepemilikan lahan hutan rakyat oleh masyarakat yang tinggal di luar kawasan hutan rakyat, namun lahan tersebut dibiarkan tanpa upaya pemanfaatan atau disebut dengan "lahan guntai”, sehingga ini menjadi persoalan lingkungan lainnya. Peran pemerintah lokal, terutama pemerintah desa dalam penanganan "lahan guntai" masih terbatas. Begitu juga upaya koordinasi dengan pemilik lahan yang tinggal 
berada di luar kawasan hutan rakyat seringkali sulit.

Pengembangan kelembagaan hutan rakyat yang tepat dapat mewujudkan performa pengelolaan hutan yang baik. Pengelolaan hutan berkelanjutan yang melibatkan aksi kolektif lokal dapat berhasil melalui penerapan prinsipprinsip: adanya aturan main pengelolaan berlandaskan norma masyarakat setempat; adanya aturan main dibuat secara partisipatif; adanya insentif ekonomi bagi pemilik dan pengguna; adanya instrumen pengendali penggunaan berkelanjutan.

Kontribusi kelembagaan formal, seperti BP3K yaitu memberikan bimbingan dan penyuluhan teknis tentang pengelolaan hutan rakyat, serta membantu kelompok tani dalam menyusun perencanaan pengelolaan hutan rakyat. Di samping itu, kelembagaan formal BLU KLHK dapat memberi bantuan berupa insentif kepada petani hutan jika melakukan penanaman tanaman berkayu di lahan miliknya. Lembaga formal UPT PK juga dapat berperan sebagai mediator yang menghubungkan kelompok tani dengan instansi/lembaga lain yang dapat bekerja sama dalam pengembangan hutan rakyat. North (2012); Sukwika et al. (2016) menekankan bahwa keberhasilan pengelolaan suatu kegiatan, sangat ditentukan oleh aspek kelembagaan karena berfungsi mengatur dan mengendalikan perilaku individu dalam masyarakat atau organisasi.

Keberhasilan efektifitas kinerja kelembagaan dalam hutan rakyat adalah SDM penyuluh dan pendampingannya. Di lain pihak, petugas penyuluh kehutanan yang ditugaskan membantu petani hutan rakyat di Kabupaten Bogor sangat terkendala dengan kekurangan jumlah tenaga penyuluh lapangan (Sukwika et al., 2016). Padahal peran penyuluh secara kelembagaan sangat strategis membantu petani hutan rakyat belajar bagaimana mendapatkan produktivitas yang lebih baik dari sistem yang dipratekan petani (McGinnis dan Ostrom, 2014). Selama ini, petani hutan rakyat yang tergabung dalam KTH belajar dari keberhasilan dan kegagalan orang lain, di mana secara regular petani berbagi pengalaman soal masalah yang hadapinya (Sukwika, 2016). Adapun program bimbingan dan penyuluhan teknis pemerintah Kabupaten Bogor yang pernah dilakukan kepada petani hutan rakyat diantaranya upaya mengubah persepsi kelompok tani dan memberikan motivasi untuk melakukan kegiatan pemberdayaan petani, konservasi tanah dan air, peningkatan produksi kayu dan non kayu, serta mekanisme penyampaian masukan-masukan program masyarakat yang diperlukan dari pihak pemerintah.

\section{KESIMPULAN DAN IMPLIKASI KEBIJAKAN}

Berdasarkan tujuan penelitian yang telah dijelaskan pada bagian pendahuluan atas, maka dapat diambil kesimpulan bahwa ditemukan tujuh aktor kunci dalam pengelolaan hutan rakyat adalah UPTD BP3K, pemilik lahan yang tinggal dari luar desa, petani pemilik, penggarap, buruh tani, penebang pohon, dan pedagang perantara (tengkulak). Dari tujuh aktor kunci terdapat tiga aktor kunci yang paling dominan di dalam ruang arena aksi hutan rakyat adalah petani pemilik, penggarap, dan tengkulak.

Terdapat tiga model kelembagaan pengelolaan hutan rakyat yang dimungkinkan untuk pengembangan kapasitas aktor yang berpengaruh di ruang hutan rakyat yaitu model kelembagaan modal usaha, model kelembagaan penanganan pemborosan sumber daya, dan model kelembagaan koordinasi.

Petani pemilik, penggarap, dan buruh tani merupakan aktor dominan di tingkat tapak yang berinteraksi langsung dengan pengelolaan lingkungan di kawasan hutan rakyat, namun secara organisasi lemah. Oleh karena itu, diperlukan konfigurasi aturan yang seimbang, yaitu harus ada proses pilihan aturan berdasarkan informasi yang relatif akurat tentang kinerja komparatif dalam lingkungan tertentu, dan mempertahankan peraturan yang berkinerja lebih baik sesuai kriteria efisiensi, keadilan, akuntabilitas, dan keberlanjutan (Ostrom, 2007).

Di lokasi penelitian ditemukan masih rendahnya respon dari instansi teknis terhadap 
masukan-masukan program dari masyarakat petani KTH. Hal ini karena masih belum memadainya kapasitas pemerintah dan koordinasi instansi pemerintah untuk menghasilkan program perbaikan dari dan untuk masyarakat petani di kawasan hutan rakyat. Oleh karena itu, ke depan para pelaku kebijakan yang terlibat di dalam ruang arena aksi hutan rakyat dapat mengoptimalkan fungsi kapasitas dan koordinasi instansi pemerintah melalui model kelembagaan koordinasi. Ditataran teknis, diperlukan pendekatan diagnostik yang kuat dalam devolusi pengelolaan hutan kepada masyarakat setempat dengan mempertimbangkan beragam sosio-ekonomi, ekologis dan penguatan kelembagaan (Sukwika et al., 2016; Okumu dan Muchapondwa, 2017). Target jangka pendeknya adalah meningkatkan kemandirian petani, menciptakan hasil kayu maupun non kayu yang berkualitas, memudahan memperoleh modal, membuka akses pasar dengan tetap menjaga kelestarian lingkungan (Adam et al., 2012; Ethika et al., 2014).

\section{DAFTAR PUSTAKA}

Adam, Y. O., Pretzsch, J., \& Pettenella, D. (2012). Contribution of Non-Timber Forest Products livelihood strategies to rural development in drylands of Sudan: potentials and failures. Agricultural $\begin{array}{llll}\text { Systems, } & 117 & \text { (C), } & \text { 90-97. }\end{array}$ https://doi.org/10.1016\%2fj.agsy.2012.12 .008

Ashari. (2006). Potensi Lembaga Keuangan Mikro (LKM) dalam Pembangunan Ekonomi Pedesaan dan Kebijakan Pengembangannya, Analisis Kebijakan Pertanian, 4 (2), 146-164.

Caballero, G. (2014). Community-based forest management institutions in the Galician communal forests: a new institutional approach. Forest Policy and Economics, $50 \quad$ (C), 347-356. https://doi.org/10.1016/j.forpol.2014.07.0 13
Canadas, M. J., Novais, A., \& Marques, M. (2016). Wildfires, forest management and landowners' collective action: a comparative approach at the local level. Land Use Policy, 56 (2016), 179-188. http://dx.doi.org/10.1016/j.landusepol.20 16.04.035

Coleman, E. A. (2009). Institutional factors affecting biophysical outcomes in forest management. Journal of Policy Analysis and Management, 28 (1), 122-146. http://dx.doi.org 10.1002/pam.20405

[Distanhut] Dinas Pertanian dan Kehutanan Kabupaten Bogor. (2014). Laporan Tahunan Pertanian dan Kehutanan. Monografi. Bogor: Distanhut.

Eriyatno. (2003). Ilmu Sistem: Meningkatkan Mutu dan Efektivitas Manajemen (jilid 1). Bogor: IPB Press.

Ethika, D., Purwanto, R. S., Senawi., \& Masyhuri. (2014). Peranan petani terhadap strategi pembangunan hutan rakyat di bagian hulu sub das logawa di Kabupaten Banyumas, Jawa Tengah. Jurnal Manusia dan Lingkungan, 21 (3), 377-385.

Hardjanto., Hero, Y., \& Trison, S. (2012). Desain kelembagaan usaha hutan rakyat untuk mewujudkan kelestarian hutan dan kelestarian usaha dalam upaya pengentasan kemiskinan masyarakat pedesaan. Jurnal Ilmu Pertanian Indonesia, 17 (2), 103-107.

Hashemnezhad, H. (2015). Qualitative Content Analysis Research: A Review Article. Journal of ELT and Applied Linguistics, 3 (1), 54-62. http://www.jeltal.com/yahoo_site_admin/ assets/docs/5.7151855.pdf

Hinings, C., Logue, D., \& Zietsma, C. (2017). Fields, governance and institutional infrastructure. SAGE Handbook of Organizational Institutionalism., 2nd Edition. R. Greenwood, C. Oliver, T.B. Lawrence, R. Meyer, Ed. Sage. 
Kartodihardjo, H. (2006). Masalah kelembagaan dan arah kebijakan rehabilitasi hutan dan lahan. Jurnal Analisis Kebijakan Kehutanan, 3 (1), 29-41.

Kasper, W., \& Streit, M. E. (1998). Institutional Economics: social order and public policy. Cheltenham: Edward Elgar.

Kriyantono, R. (2012). Teknik praktis riset komunikasi, Edisi 6. Jakarta: Kencana Prenada Media Group

Kyfyak, V. (2012). The institutional mechanism of development of the agricultural sector of Ukraine. Ecoforum, 1 (1), 2012

McGinnis, M. D., \& Ostrom, E. (2014). Socialecological system framework: initial changes and continuing challenges. Ecology and Society, 19 (2), 30. http://dx.doi.org/10.5751/ES-06387190230

Mokhele, M. (2018). The volatility of institutional arrangements that influence development: The case of Bram Fischer International Airport in South Africa. The Journal for Transdisciplinary Research in Southern Africa, $14 \quad$ (1). https://doi.org/10.4102/td.v14i1.436

North, D. C. (2012). Institutions, Institutional Change and Economic Performance. New York: Cambridge University Press. https://doi.org/10.1017/CBO9780511808 678

Okumu, B., \& Muchapondwa, E.(2017). Determinants of successful collective management of forest resources: evidence from Kenyan community forest associations. ERSA working paper 698

Osei-Tutu, P., Pregernig,M., \& Pokorny, B. (2015). Interactions between formal and informal institutions in community, private and state forest contexts in Ghana. Forest Policy and Economics, 54 (C), 2635.

https://doi.org/10.1016/j.forpol.2015.01.0 06

Ostrom, E. (2007). Developing a Method for Analyzing Institutional Change. Center for the Study of Institutional Diversity. Arizona: Arizona State University
Ostrom, E. (2008). Doing institutional analysis: digging deeper than markets and hierarchies. Handbook of New Institutional Economics. Menard C, Shirley M., Ed.. Berlin: Springer-Verlag Berlin Heidelberg

Ostrom, E. (2011). Background on the institutional analysis and development framework. Policy Studies Journal, 39 (1), 7-27. http://dx.doi.org/ 10.1111/j.1541-0072.2010.00394.x

Persson, J., \&Prowse, M. (2017). Collective action on forest governance: An institutional analysis of the Cambodian community forest system. Forest Policy and Economics, 83 (C), 70-79, https://doi.org/10.1016/j.forpol.2017.06.0 08

Riduwan. (2009). Pengantar Statistika Sosial. Bandung: Alfabeta

Rout, S. (2011). Collective action for sustainable forestry: institutional dynamics in community management of forest in Orissa. Social Change, 40 (4), 479-502. http://dx.doi.org/10.1177/004908571004 000405

Saxena, J. P., Sushil., \& Vrat, P. (1992). Hierarchy and classification of program plan elements using interpretive structural modeling. Systems Practice, 5 (6), 651670. https://doi.org/10.1007/BF01083616

Saxena, J. P., Sushil, \& Vrat, P. (2006). Policy and Strategy Formulation: an application of flexible systems methodology. Global Institute of Flexible Systems Management, New Delhi: GIFT Publishing

Setiawan. H., Barus, B., \& Suwardi. (2014). Analisis potensi pengembangan hutan rakyat di Kabupaten Lombok Tengah. Majalah Ilmiah Globë, 16 (1), 69-76

Sukisman, S. R. H., \& Setiawan, B. (2011). Partisipasi masyarakat anggota koperasi hutan jaya lestari dalam pembangunan hutan rakyat di Kabupaten Konawe Selatan. Majalah Geograf Indonesia, 25 (2), $178-197$ 
Sukwika, T. (2016). Evaluasi model kebijakan pengelolaan hutan rakyat berkelanjutan di Kabupaten Bogor [Disertasi]. Bogor (ID): Institut Pertanian Bogor

Sukwika, T., Darusman, D., Kusmana, C., \& Nurrochmat, D. R. (2016). Evaluating the level of sustainability of privately managed forest in Bogor, Indonesia. Biodiversitas, $17 \quad$ (1), 241-248. http://dx.doi.org/10.13057/biodiv/d17013 5

Sushil. (2012). Interpreting the Interpretive Structural Model. Global Journal of Flexible Systems Management, 13 (2), 87106. http://dx.doi.org/10.1007/s40171012-0008-3

Susila, I. (2007). Analisis efisiensi lembaga keuangan mikro. Jurnal Ekonomi Pembangunan, 8 (2), 223-242, https://doi.org/10.23917/jep.v8i2.1043

Suyanto B. (2005). Metode Penelitian Sosial berbagai Alternatif Pendekatan. Jakarta: Prenada

Thompson, R. (2011). Stakeholder Analysis. Winning Support for Your Projects. http://www.mindtools.com/pages/article/ newPPM_07.htm

Tiwari, B. K., Tynsong, H., Lynrah, M. M., Lapasam, E., Deb, S., \&Sharma, D. (2013). Institutional arrangement and typology of community forests of Meghalaya, Mizoram and Nagaland of North-East India. Journal of Forestry Research, 24 (1), 179-186

Umar, H. (2002). Metode riset komunikasi organisasi. Jakarta: PT. Gramedia Pustaka Utama

Yamane T. (1967). Statistics: An introductory analysis, 2nd Ed. New York: Harper and Row 